\title{
ADAPTATION TO SPANISH OF AN ETHNOCULTURAL EMPATHY SCALE $^{1}$
}

\author{
María-Jesús Albar², Manuel García-Ramírez ${ }^{3}$ Pedro Perez Moreno ${ }^{4}$, Violeta Luque-Ribelles ${ }^{5}$, Rocio Garrido ${ }^{6}$, \\ Anna Bocchino ${ }^{7}$
}

${ }^{1}$ This study was conducted in the project - Community Cultural Competence: competent professionals for various communities, funded by the Ministry of Economy and Finance of Spain (2011-2554 PSI).

${ }^{2}$ Ph.D. in Psychology. Faculty and Researcher, Nursing Department, School of Nursing, Physiotherapy and Podology, Universidad de Sevilla. Sevilla, Spain. E-mail: mja@us.es

${ }^{3}$ Ph.D. in Psychology. Faculty and Research, Social Psychology Department, School of Psychology, Universidad de Sevilla. Sevilla, Spain. E-mail: magarcia@us.es

${ }^{4}$ Ph.D. in Psychology. Teaching Staff and Researcher, Department of Clinical, Experimental and Social Psychology, Universidad de Huelva. Huelva, Spain. E-mail: pedro.perez@dpsi.uhu.es

${ }^{5}$ Ph.D. in Psychology. Teaching Staff and Researcher, Psychology Department, School of Educational Sciences, Universidad de Cádiz. Puerto Real, Spain. E-mail: violeta.luque@uca.es

${ }^{6}$ Graduated in Psychology. Research Trainee, Social Psychology Department, School of Psychology. Universidad de Sevilla. Sevilla, Spain. E-mail: rocioga@us.es

7 Ph.D. in Psychology. Teaching Staff and Researcher, School of Nursing “Salus Infirmorum”. Universidad de Cádiz. Puerto Real, Spain. E-mail: anna.bochinno@libero.it

ABSTRACT: The aim of this study is to adapt the Ethnocultural Empathy Scale of Wang, et al. to Spanish. A process of translation and back-translation of the items was carried out and their psychometric properties were explored in a sample of 441 nursing students from universities in Western Andalusia. Exploratory analyses were used to form sets of items that would reduce the number of indicators for each latent factor in the confirmatory analysis. After obtaining the sets of items, we tested the fit of the data to two factorial structures: a model with four interrelated first-order factors, and another with a second-order factor composed of four first-order factors. The factor structure of the original scale and an appropriate reliability and validity are confirmed. The results obtained support the utilization of the Spanish version of this scale with students of health sciences.

DESCRIPTORS: Empathy. Cultural diversity. Validation studies. Questionnaires.

\section{ADAPTAÇÃO AO ESPANHOL DE UMA ESCOLA DE EMPATIA ETNOCULTURAL}

RESUMO: O objetivo deste estudo é a adaptação para espanhol da escala de empatia etnocultural de Wang, et al. Foi realizado um processo de tradução e retrotradução dos itens e as suas propriedades psicométricas foram exploradas numa amostra de 441 estudantes de Enfermagem de universidades da Andaluzia Ocidental. As análises exploratórias foram utilizadas para agrupar os itens, o que reduziu o número de indicadores de cada fator na análise confirmatória. Testou-se o ajuste dos dados a duas estruturas fatoriais: um modelo com quatro fatores de primeira ordem inter-relacionados e outro com um fator de segunda ordem composto por quatro fatores de primeira ordem. Confirma-se a estrutura fatorial da escala original e uma adequada fiabilidade e validade externa. Os resultados apoiam a utilização da versão espanhola desta escala em estudantes de ciências da saúde.

DESCRITORES: Empatia. Diversidade cultural. Estudos de validação. Questionários.

\section{ADAPTACIÓN AL ESPAÑOL DE UNA ESCALA DE EMPATÍA ETNOCULTURAL}

\begin{abstract}
RESUMEN: El objetivo de este estudio es adaptar al español la escala de Empatía Etnocultural de Wang, et al. Se llevó a cabo un proceso de traducción y retrotraducción de los ítems y se exploraron sus propiedades psicométricas en una muestra de 441 estudiantes de Enfermería de universidades de Andalucía Occidental. Los análisis exploratorios se emplearon para formar paquetes de ítems que permitieran reducir el número de indicadores de cada factor latente en los análisis confirmatorios. Se puso a prueba el ajuste de los datos a dos estructuras factoriales: un modelo con cuatro factores de primer orden relacionados entre sí, y otro con un factor de segundo orden compuesto por cuatro factores de primer orden. Se confirma la estructura factorial de la escala original y una adecuada fiabilidad y validez externa. Los resultados apoyan la utilización de la versión española de esta escala en estudiantes de ciencias de la salud. DESCRITORES: Empatia. Diversidade cultural. Estudos de validação. Questionários.
\end{abstract}




\section{INTRODUCTION}

Guaranteeing the equity of health services for ethnoculturally different population is a challenge for the health policy agendas of countries in the European Union. ${ }^{1}$ Multiple studies have revealed higher mortality and morbidity rates among immigrant users, as well as lesser satisfaction with the health care received. ${ }^{2-3}$ This is partially due to the health professionals' difficulties to empathize with users from different ethnocultural groups, which limit their ability to establish effective communication and cooperation channels with them. ${ }^{4-5}$

In Spain, the recent literature manifests the need to train the health professionals in competences that allow them to successfully face the cultural differences with the users of their services. ${ }^{6-7}$ In this context, the intercultural dialogue is of great value, ${ }^{8}$ which demands furthering strategies that facilitate increased awareness of their own cultural bias, putting themselves in the users' place, and delivering people-centered care. ${ }^{9}$ This initial process means that these professionals are able to successfully empathize with people from distinct ethnic-cultural groups. Ethnocultural Empathy is defined as "a learned capacity and a measurable personal trait, which consists in empathy towards people from other racial and ethnic groups, which are different from our own ethnocultural group" ${ }^{\prime 10: 222-3}$

To respond to this challenge, cultural skills or competency training programs have targeted the health service professionals as part of continuing education programs that intend to respond to the population's demographic changes. Nevertheless, the European scientific community has called attention to the need to start the cultural sensitization of future health professionals since University, which requires the training of the teachers. ${ }^{11-12}$ At the same time, the need is evidenced to develop assessment tools that permit monitoring the learning process. ${ }^{13-14}$ The Scale of Ethnocultural Empathy ${ }^{10}$ is an appropriate tool for this purpose. It is therefore our intention to contribute to this challenge by adapting it to Spanish.

To develop this scale, the theoretical framework of general empathy and cultural empathy was used. ${ }^{15-16}$ Departing from an initial list of 71 items, the authors obtained a 31-item scale with appropriate psychometric properties. To get to know the internal structure, first, exploratory factorial analysis was applied, confirming its results through a confirmatory factorial analysis in a second sample. Following the process proposed by some authors ${ }^{17}$, the structure obtained based on item clusters comprises four first-order factors that are grouped in a single second-order factor. The four factors are called and interpreted as follows: (a) Empathetic Feelings and Expressions, centered on the emotional reactions an individual experiences when (s)he observes or learns about discriminatory experiences and emotions of people from different ethnic origins; (b) Having an Empathetic Perspective, related to the effort to understand the emotions and experiences of people from ethnic origins different from one's own, in view of their perspectives on the world; (c) Acceptance of Cultural Differences, linked to the understanding and acceptance of traditions and cultural customs of other ethnic groups (d) Empathetic Awareness, identified as the knowledge of discriminatory experiences people from other ethnic groups are submitted to in different social contexts (communication media, institutions, etc.). The same factorial structure was confirmed in the adaptation of the scale to Italian ${ }^{18}$ and to Swedish. ${ }^{19}$ Similarly, its negative correlation with measures of prejudice and its importance to capture the gender differences in the empathetic reaction have been manifested. ${ }^{10,18}$

Based on this background, the objectives in this study are to adapt an ethnocultural empathy scale to Spanish, ${ }^{10}$ to determine its psychometric properties and obtain evidence on its validity, related to its internal structure and the variables of subtle and blatant prejudice.

\section{METHODS}

The adaptation to Spanish and validation of a scale was chosen as the study design. The data were collected through a survey.

The research context included the Schools of Nursing at the Universities of Sevilla, Cádiz and Huelva, in the Autonomous Community of Andalusia (Spain). Based on a convenience sample, 441 Spanish students were selected in the first three subjects taught in the nursing program at the three participating universities.

To measure the research variables, the following tools were used: (a) register of sociodemo- 
graphic data, which collected information about the participants' age, sex, course and university; (b) Ethnocultural Empathy. The Spanish version of the Ethnocultural Empathy scale was used, adapted following the phases recommended in the literature..$^{20}$ To guarantee the conceptual equivalence of the items, first, the direct and backtranslation of the original items in English was performed. Qualified translators were responsible for this process, after which Wang reviewed and approved the translation. The Spanish version of the scale is displayed in Attachment 1. The adapted scale includes 31 items that produce a total score, and four scales corresponding to the subscales Empathetic Feelings and Expressions, which consists of 15 items $(3,9,11,12,13,14,15$, 16, 17, 18, 21, 22, 23, 26, 30); "Having an Empathetic Perspective", 7 items $(2,4,6,19,28,29,31)$; Acceptance of Cultural Differences, 5 items (1, $5,8,10,27)$, and Empathetic Awareness, 4 items $(7,20,24,25)$. In the response format, the level of agreement with the items is measured on a fivepoint Likert scale $(1=$ I strongly disagree to $5=\mathrm{I}$ strongly agree). Negatively formulated items are scored backwards. (c) Blatant and Subtle Prejudice. Prejudice is a negative affective response that leads to the rejection of the individuals who do not belong to the endogroup. In this study, the Spanish version ${ }^{21}$ of the scale of Subtle and Blatant Prejudice ${ }^{22}$ was used, which consists of 20 items. Ten items correspond to the measuring of blatant prejudice, considered as a direct response of rejection and aggressiveness towards immigrants, and the remaining items to subtle prejudice, characterized as a cold, distant and indirect reaction, with a lesser manifestation of emotions or feelings towards immigrants. In both scales, the level of agreement with the items is measured on a five-point Likert scale (1= I strongly disagree to $5=$ I strongly agree). This scale was chosen to assess the external validity of the Ethnocultural Empathy scale.

The data were collected in April and May 2013. The students self-completed the scales after signing the informed consent form. This project received approval from the Institutional Review Board of the University of Sevilla, under protocol PSI2011-2554.
Cases were analyzed in which all scale items had been answered, which means that no procedures were undertaken to calculate lost values. The statistical software Statistical Package for the Social Sciences (SPSS) 15.0 was used to estimate the reliability and to undertake the exploratory factorial analysis; for the confirmatory factorial analysis, the software EQS 6.0 was adopted.

\section{RESULTS}

Approximately $40.4 \%$ of the participants corresponded to the University of Sevilla, 29.9\% to Huelva and $29.7 \%$ to Cádiz. $81.6 \%$ of the sample was female. The ages ranged between 18 and 47 years $(\mathrm{M}=21.6$ years; $\mathrm{SD}=4.47)$.

\section{Estimated reliability}

The Cronbach's alpha coefficient for the full scale was 0.88 . On the other hand, adopting the same procedure, the reliability estimated for the components Empathetic Feelings and Expressions, Having an Empathetic Perspective, Acceptance of Cultural Differences and Empathetic Awareness reached the following coefficients, respectively: $0.86,0.53,0.69$ and 0.70 .

\section{Factorial structure}

To undertake the analysis of the factorial structure by means of a confirmatory procedure, the steps described in the original article about the scale were followed..$^{10}$ First, the sample was divided in two halves through a simple random sampling procedure. Both halves were equivalent in terms of the participants' sex ( $\chi^{2}$ correction $(1$; $\mathrm{N}=412)=0.265 ; p=0.607)$ and age $(t(404 ;$ bilateral $)$ $=0.983 ; p=0.326)$. The fist sample $(n=198)$ was used in the exploratory analysis and the second $(n=214)$ in the confirmatory analysis. The exploratory analyses were used to constitute item clusters, which permitted reducing the number of indicators of each latent factor in the confirmatory analyses. The saturations of the items in their respective components and the items in each cluster are displayed in Table 1. 
Table 1 - Saturations of the items in their respective first-order components and distribution in clusters. School of Nursing of Sevilla, Cádiz and Huelva, 2013

\begin{tabular}{|c|c|c|c|c|c|c|c|c|}
\hline \multirow{2}{*}{ Cluster 1} & \multicolumn{2}{|c|}{ Component 1} & \multicolumn{2}{|c|}{ Component 2} & \multicolumn{2}{|c|}{ Component 3} & \multicolumn{2}{|c|}{ Component 4} \\
\hline & Item 11 & 642 & Item 2 & 129 & Item 1 & 661 & Item 20 & 634 \\
\hline & Item 12 & 799 & Item 28 & 772 & Item 10 & 791 & Item 24 & ,816 \\
\hline & Item 13 & 663 & Item 29 & ,583 & & & & \\
\hline & Item 17 & ,479 & & & & & & \\
\hline & Item 30 & 604 & & & & & & \\
\hline \multirow[t]{5}{*}{ Cluster 2} & Item 9 & ,427 & Item 31 & 658 & Item 5 & ,561 & Item 25 & ,743 \\
\hline & Item 15 & 746 & Item 6 & 456 & Item 8 & 712 & & \\
\hline & Item 18 & 631 & & & Item 27 & 687 & & \\
\hline & Item 21 & 661 & & & & & & \\
\hline & Item 26 &, 531 & & & & & & \\
\hline \multirow[t]{5}{*}{ Cluster 3} & Item 3 & ,486 & Item 19 & 643 & & & Item 7 & 651 \\
\hline & Item 14 & 630 & Item 4 & 243 & & & & \\
\hline & Item 16 & ,313 & & & & & & \\
\hline & Item 22 & 675 & & & & & & \\
\hline & Item 23 & 658 & & & & & & \\
\hline
\end{tabular}

After obtaining the item clusters, the fit of the data to two factorial models was tested: one with four interrelated first-order factors (Model A) and the other with one second-order factor that consisted of four first-order factors (Model
B). In both cases, the maximum likelihood estimation was used. In Figures 1 and 2, the factorial structures of the models and the standardized estimated regression coefficients and results of the $\chi^{2}$ test are shown.

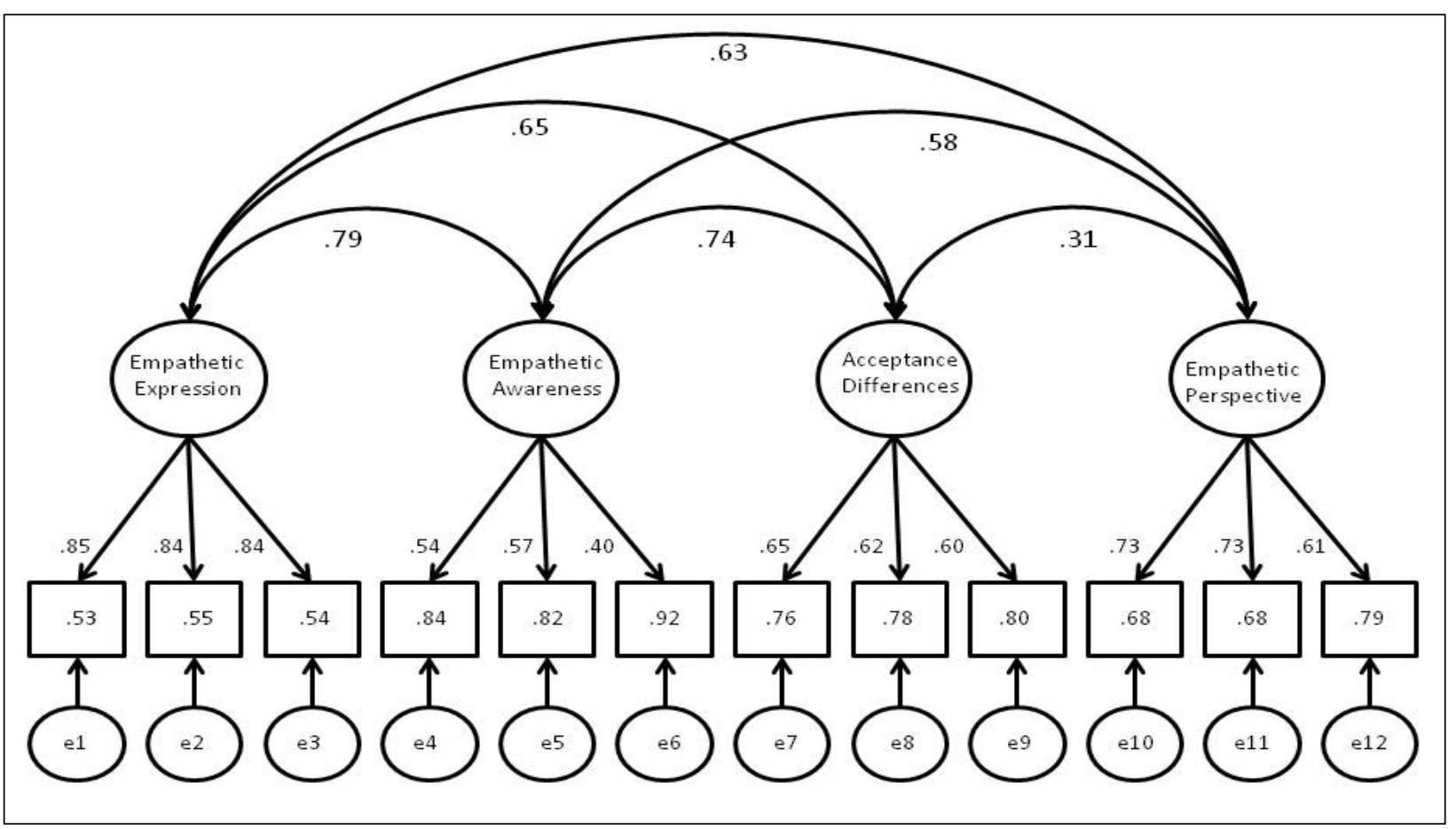

$X_{(48)}^{2}=98.761 ; \mathrm{p}=0.000 ; \chi^{2} / \mathrm{gl}=2.058$

Figure 1 - Factorial structure of Model A 


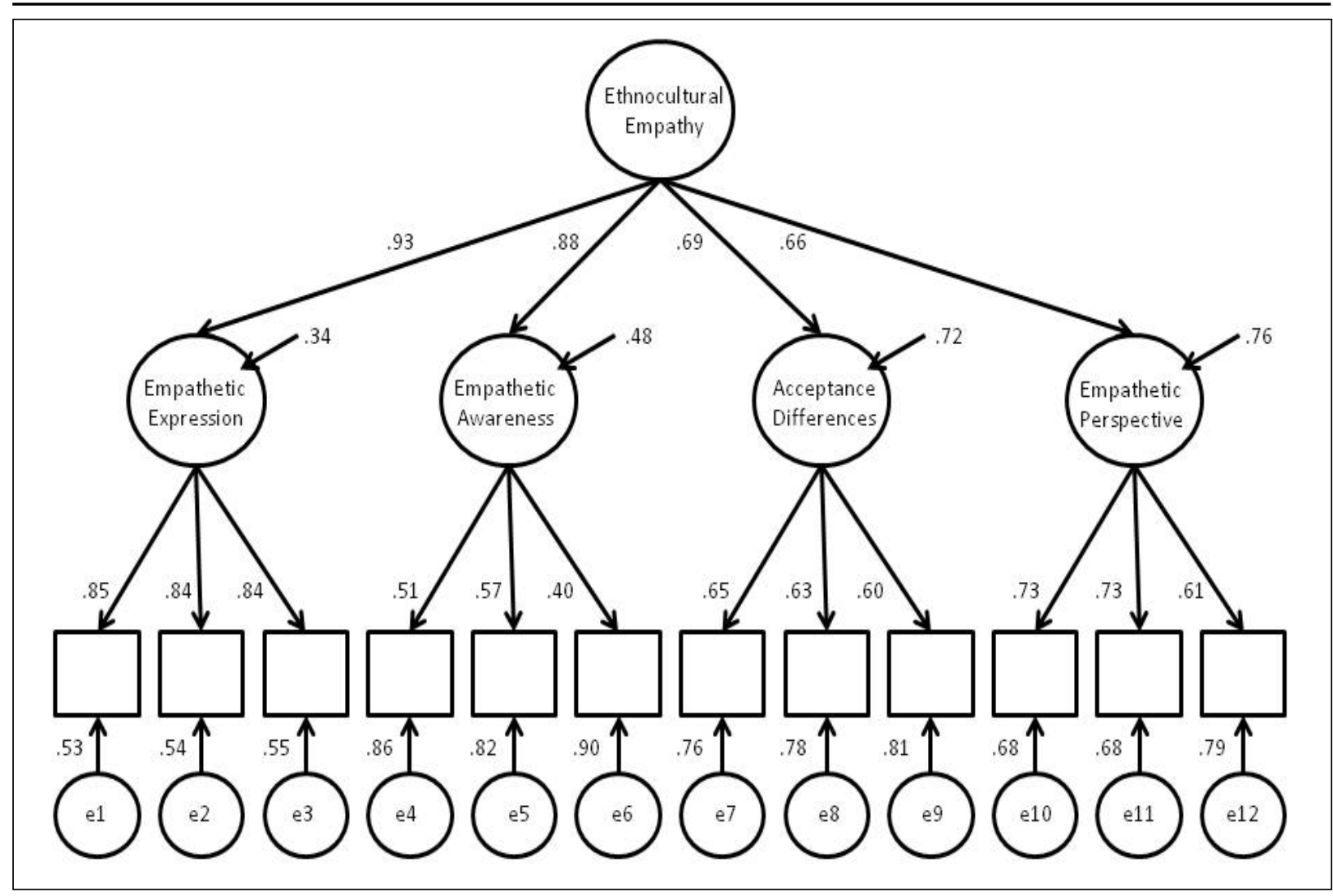

$\chi_{(50)}^{2}=107.152 ; \mathrm{p}=0.000 ; \chi^{2} / g l=2.143$

\section{Figure 2 - Factorial structure of Model B}

The fit coefficients of both models are displayed in Table 2. To discover the goodness of fit of both models, the $\chi^{2}$ test and the $\chi^{2} /$ gl index were interpreted. Both $\chi^{2}$ tests are statistically significant, as well as the $\chi^{2} / \mathrm{gl}$ indices of both models, inferior to $3.0^{23}$. Also, the Normed-Fit-Index (NFI), Non-Normed-Fit-Index (NNFI), Goodness-ofFit-Index (GFI), Incremental-Fit-Index (IFI) and Comparative-Fit-Index (CFI) were interpreted. The fit was considered appropriate if these indices were equal to or higher than $0.90 .{ }^{24}$ In both cases, only the NFI (sensitive to deviations from normality) was inferior to 0.90 , while the remainder indicated the appropriate adjustment of both models. Therefore, the fit of both models can be considered appropriate. In addition, the Standardized Root Mean-Square (SRMR) was interpreted, which is considered appropriate when inferior to 0.08, as well as the Root Mean Square Error of Approximation (RMSEA), appropriate when equal or inferior to $0.08 .{ }^{24}$ Like the rest of the indices, this interpretation provides favorable evidence on the adjustment of both models.

To compare both models, the contrast between the differences of both models' $\chi^{2}$ coefficients was used. The results shows $X^{2}(2$, $\mathrm{N}=214)=8.391$, with $p=0.0151$. Therefore, it can be considered that a statistically significant difference exists in the goodness-of-fit of both models. ${ }^{25}$ In addition, the difference between both comparativefit-indices (CFI) was analyzed, corresponding to 0.008 , inferior to 0.01 , which indicates that it cannot be affirmed that relevant differences exist in the goodness-of-fit of both models. Therefore, insufficient evidence was found to affirm that one model is more appropriate than the other to interpret the data obtained.

Finally, to collect evidence on the validity of the scale in relation to other variables, the correlation with blatant $(\alpha=.82)$ and subtle $(\alpha=.73)$ prejudice was calculated. Pearson's correlation between the weighted Ethnocultural Empathy scale and the participants' blatant and subtle loss corresponded to $-0.588(\mathrm{p}<0.001)$ and -0.586 $(\mathrm{p}<0.001)$, respectively. 
Table 2 - Goodness-of-fit indicators of the models. School of Nursing of Sevilla, Cádiz and Huelva, 2013

\begin{tabular}{lccccccc}
\hline & NFI $^{*}$ & NNFI $^{\dagger}$ & CFI $^{\ddagger}$ & GFI $^{\S}$ & IFI $^{||}$ & RMSEA $^{\text {}}$ & 90\%RMSEA $^{\text {90RM }}$ \\
\hline Model A & .891 & .971 & .940 & .934 & .941 & .070 & $.050-0.90$ \\
Model B & .882 & .911 & .932 & .926 & .933 & .073 & $.054-0.92$ \\
\hline
\end{tabular}

${ }^{*}$ Normed-Fit-Index; ${ }^{\dagger}$ Non-Normed-Fit-Index; ${ }^{\ddagger}$ Comparative-Fit-Index; ${ }^{\circledR}$ Goodness-of-Fit-Index; $\mid$ Incremental-Fit-Index; ${ }^{\circ}$ Root Mean Square Error of Approximation.

\section{DISCUSSION}

The objective in this study was to adapt the Ethnocultural Empathy scale ${ }^{10}$ to Spanish and the assess its psychometric properties in a sample of nursing students from Andalusia.

The results confirm that the Spanish version possesses the same factorial structure as the original scale and the adaptations to Italian and Swedish. ${ }^{18-19}$ Although the model with four interrelated components obtains better goodness-of-fit indices, insufficient evidence was found to affirm that this model is preferable to the model with one second-order factor consisting of four first-order factors. What the validity of the scale in relation to blatant and subtle prejudice is concerned, the results are in line with other authors, ${ }^{18}$ who found a negative relation between these variables and ethnocultural empathy.

The appropriate psychometric properties of the Spanish validation of the scale provide theoretical support for the original ethnocultural empathy construct and demonstrates its proper functioning in a distinct cultural context. In practice, the adaptation and validation of this scale to Spanish can be very useful in student education and health professional training. In the first place, this tool provides evidence of the extent to which the curricular training of health science students (nursing, medicine, psychology etc.) is considering the competences to appropriately treat the health problems of people from distinct cultures and ethnic origins. In the second place, the ability to measure the ethnocultural empathy of professionals in the health contexts serves to design the cultural competency training and to prove its effectiveness.

According to some cultural competency models, ${ }^{9,25}$ having ethnocultural empathy does not mean being effective in interventions involving users, but is the first and fundamental step to achieve this. It has been observed that, on some occasions, the professionals are unaware of their prejudice towards people from other cultures, with negative consequences for the establishment of the therapeutic relationship. ${ }^{4}$ The ability to change an attitude of blatant or subtle rejection to an empathetic attitude towards these people is a fundamental requisite to stimulate the knowledge and understanding about the influence of culture on the manifestation of health problems. Similarly, it is also the route to achieve greater equity in health. Finally, although the validation involved nursing students, this scale can also be applied to students from other health science areas, as well as to primary and specialized care professionals working in multicultural contexts.

Among the study limitations, it is important to mention that, as these measures were selfinformed, the social desirability bias cannot be ignored. Nevertheless, the participants' anonymity can guarantee the veracity of the answers. On the other hand, most students were women, which is common in research involving nurses or nursing students, as the profession is eminently female. Examining the factorial structure in heterogeneous samples would provide empirical evidence on the role of gender in empathetic responses and would strengthen previous findings. ${ }^{10,19}$

\section{CONCLUSION}

In conclusion, the psychometric properties of the Spanish version of the ethnocultural empathy scale are appropriate and represent a first step towards its use in the care, teaching and research context. In concrete terms, it can be useful as an initial measure of current and future health professionals' cultural competency acquisition process, with a view to determining the need to undertake specific ethnocultural competency training programs and assessing the evolution of the training process.

\section{REFERENCES}

1. European Commission. Communication from the commission to the European Parliament, the Council, the European Economic and Social Committee and the Committee of the Regions on 
Solidarity in health: Reducing health inequalities in the EU. Brussels (BE): European Commission; 2009.

2. Albin B, Hjelm K, Ekberg J, Elmstahl S. Higher mortality and different pattern of causes of death among foreign-born compared to native Swedes 1970-1999. J Immigr Minor Health. 2006 Apr; 8(2):101-13.

3. Norredam M, Olsbjerg M, Petersen JH, Laursen B, Krasnik A. Are there inequalities in mortality among refugees and immigrants compared to native Danes -a historical prospective cohort study BMC Public Health. 2012 Sep 10; 12:757.

4. Cooper L, Beach M, Johnson R, Inui TS. Delving below the surface. Understanding how race and ethnicity influence relationships in health care. J Gen Intern Med. 2006 Jan; 21(Suppl 1):S21-7.

5. Ingleby D. Etnicidad, migración y la agenda de "los Determinantes Sociales de la Salud". Psychosocial Intervent. 2012; 21(3):1-13.

6. Fuertes C, Martín MA. El inmigrante en la consulta de atención primaria. An Sist Sanit Navar. 2006; 29(Suppl 1):9-25

7. Vázquez Navarrete ML, Terraza Núñez R, Vargas Lorenzo I, Lizana Alcazo T. Necesidades de los profesionales de la salud en la atención a la población inmigrante. Gac Sanit. 2009 Sep-Oct; 23(5):396-402.

8. Gilbert J. Reflecting on intercultural dialogue in nursing. Texto Contexto Enferm. 2006 Jan-Mar; 15(1):131-6

9. Weaver HN. Striving for cultural competence: moving beyond potential and transforming the helping professions. In: Dana $\mathrm{RH}$, Allen J, editors. Cultural competency training in a Global society. New York (US): Springer; 2008. p.135-55

10. Wang YW, Bleier J, Davidson M, Bielstein HB, Tan JA, Beier JK. The scale of ethnocultural empathy: development, validation, and reliability. J Couns Psychol. 2003; 50(2):221-34.

11. Dogra N. Cultural diversity teaching in the medical undergraduate curriculum. Diversity Health Social Care. 2005; 2(3):233-45

12. González-Gil T, Martínez-Gimeno L, LuengoGonzález R. Antropología de los cuidados en el ámbito académico de Enfermería en España. Texto Contexto Enferm. 2006 Jan-Mar; 15(1):155-61

13. Seeleman C, Suurmond J, Stronks K. Cultural competence: a conceptual framework for teaching and learning. Med Educ. 2009; 43(3):229-37
14. Hudelson P, PerronNJ, Perneger TV. Measuring physicians' and medical students' attitudes toward caring for immigrant patients. Eval Health Prof. 2010 Dec; 33(4):452-72.

15. Duan C, Hill CE. The current state of empathy research. J Couns Psychol. 1996; 43(3):261-74.

16. Ridley CR, Lingle DW. Cultural empathy in multicultural counseling: A multidimensional process model. In: Pedersen PB, Draguns JG, editors. Counseling across cultures. $4^{\text {th }}$ ed. Thousand Oaks (US): Sage; 1996. p.21-46

17. Russell DW, Kahn JH, Spoth R, Altmaier EM. Analyzing data from experimental studies: A latent variable structural equation modeling approach. J Couns Psychol. 1998; 45(1):18-29.

18. Albiero P, Matricardi G. Empathy towards people of different race and ethnicity: Further empirical evidence for the scale of ethno-cultural empathy. Int J Intercult Relat. 2013; 37(5):648-55

19. Rasoal C, Jungert T, Hau S, Andersson G. Development of a Swedish version of the scale of ethnocultural empathy. Psycology. 2011; 2(6): 568-73.

20. Muñiz J, Hambleton R. Adaptación de los test de unas culturas a otras. Metodol Ciencias Comport. 2000; 2(2):129-49.

21. Rueda JF, Navas M. Hacia una evaluación de las nuevas formas de prejuicio racial: las actitudes sutiles del racismo. Rev Psicol Soc. 1996; 11(2):13149.

22. Pettigrew TF, Meertens RW. Subtle and blatant prejudice in Western Europe. Eur J Soc Psychol. 1995; 25(1):57-75.

23. Carmines EG, McIver JP. Analyzing models with unobserved variables. In: Bohrnstedt GW, Borgatta $\mathrm{EF}$, editors. Social measurement: current issues. Beverly Hills (US): Sage; 1981. p.122-3

24. Hu L, Bentler P. Cutoff criteria for fit indexes in covariance structure analysis: conventional criteria versus new alternatives. Struct Equation Modeling. 1999; 6(1):1-55.

25. Balcázar F, Suarez-Balcázar Y, Willis C, GarcíaRamírez M. Cultural competence: a review of conceptual frameworks. In: Balcázar F, SuárezBalcázar Y, Taylor-Ritzler T, Keys C, editors. Race, culture, and disability: rehabilitation science and practice. Boston (UK): Jones \& Bartlett; 2010. p.281305. 


\section{Attachment 1. Ethnocultural empathy scale (Spanish version)}

Items

1. Me siento enfadado/a cuando la gente no habla mi idioma

2. Desconozco mucha información acerca de acontecimientos importantes sociales y políticos de grupos raciales o étnicos distintos al mío.

3. Me conmueven películas o libros sobre cuestiones de discriminación a grupos raciales o étnicos distintos al mío.

4. Sé lo que se siente siendo la única persona de raza o etnia distinta en un grupo de personas

5. Me impaciento cuando me comunico con personas de otros grupos raciales o étnicos a pesar de lo bien que hablan mi idioma.

6. Puedo comprender la frustración que sienten algunas personas al tener menos oportunidades debido a su origen racial o étnico.

7. Soy consciente de las barreras institucionales (ej., oportunidades restringidas para la promoción de empleo) que discriminan a grupos raciales o étnicos diferentes al mío.

8. No entiendo porqué las personas de diferentes razas o etnias disfrutan al llevar sus vestidos tradicionales.

9. Busco oportunidades para hablar con personas de otro origen racial o étnico acerca de sus experiencias.

10. Me irrito cuando las personas de diferente origen étnico o racial hablan su idioma a mí alrededor.

11. Defiendo a mis amigos/as cuando son tratados injustamente por su origen racial o étnico.

12. Comparto el enfado de aquellos/as que son víctimas de injusticias por su origen racial o étnico.

13. Muestro aprecio por sus normas culturales cuando interactúo con personas de otro origen racial o étnico.

14. Siento que apoyo a otros grupos raciales y étnicos, si creo que se están aprovechando de ellos.

15. Me molesta que otras personas sufran desgracias por su origen racial o étnico.

16. Raramente pienso en el impacto que pueden tener las bromas racistas sobre los sentimientos de las personas a las que están dirigidas.

17. No es probable que participe en eventos que promueven la igualdad de derechos para las personas de otros grupos raciales y étnicos.

18. Expreso mi preocupación por la discriminación a personas de otros grupos raciales o étnicos.

19. Es fácil para mí entender lo que sentiría siendo una persona de otra raza o etnia.

20. Puedo ver como otros grupos raciales o étnicos son sistemáticamente oprimidos en nuestra sociedad.

21. No me importa si la gente hace afirmaciones racistas contra otros grupos raciales o étnicos.

22. Cuando veo que personas de diferentes orígenes raciales o étnicos tienen éxito en el espacio público, comparto su orgullo.

23. Cuando otras personas luchan contra la opresión étnica o racial, comparto sus frustraciones.

24. Reconozco que los medios de comunicación describen a las personas basándose en estereotipos raciales o étnicos.

25. Soy consciente de cómo la sociedad trata de forma diferente a las personas de orígenes raciales o étnicos distintos al mío.

26. Comparto la ira de las personas que son víctimas de delitos raciales (por ejemplo, la violencia intencional debida a la raza o etnia).

27. No entiendo porque las personas de otros orígenes raciales o étnicos quieren mantener sus tradiciones culturales, en lugar de intentar ajustarse a la cultura dominante.

28. Es difícil ponerme en el lugar de alguien que sea racial o étnicamente diferente a mí.

29. Me siento incómodo/a cuando estoy alrededor de un número significativo de personas que son racial o étnicamente diferentes a mí.

30. Cuando oigo a las personas hacer bromas racistas, les digo que me molestan a pesar de que no se refieran a mi grupo racial ó étnico.

31. Es difícil para mí entender historias en las que las personas cuentan la discriminación racial o étnica que experimentan en sus vidas cotidianas. 